\title{
ANALYTICAL METHODOLOGY FOR TESTING COMMON RAIL FUEL INJECTORS IN PROBLEMATIC CASES
}

\section{Tomasz STOECK}

West Pomeranian University of Technology in Szczecin, Faculty of Mechanical Engineering and Mechatronics, The Department of Automotive Engineering, Piastów Av. 19, 70-310 Szczecin, Poland, e-mail: tstoeck@wp.pl

\section{Abstract}

The paper presents a new methodology for testing common rail fuel injectors, which extends the standard diagnostic procedure to include the analysis of the resultant fields of dosed fuel. The calculations were made on the basis of Gaussian formulas, also known as the shoelace formula. Their implementation in the digital environment was convenient from the practical side, as it eliminated the need to modify the test bench software. Thanks to the easy modification, the presented algorithms can be used in testing fuel injectors of other types or generations, for which clear assessment and verification of the technical condition is sometimes difficult. It is not required for this to increase the number of measuring points of the active experiment, which is one of the greatest advantages of the proposed solution.

Keywords: common rail fuel injector, extension of test procedures, Gauss's formulas, fuel dosage

\section{ANALITYCZNA METODYKA BADAŃ WTRYSKIWACZY COMMON RAIL W PRZYPADKACH PROBLEMATYCZNYCH}

\section{Streszczenie}

W artykule przedstawiono nową metodykę testowania wtryskiwaczy common rail, która rozszerza standardową procedurę diagnostyczną o analizę wynikowych pól dawkowanego paliwa. Obliczenia prowadzono w oparciu o wzory Gaussa, określane również mianem formuły sznurowadła. Ich implementacja w środowisku cyfrowym była wygodna od strony praktycznej, gdyż wyeliminowała konieczność modyfikacji oprogramowania stołu probierczego. Dzięki łatwej modyfikacji prezentowane algorytmy można wykorzystać w badaniach wtryskiwaczy innych typów czy generacji, dla których jednoznaczna ocena i weryfikacja stanu technicznego bywa utrudniona. Nie jest przy tym wymagane zwiększanie liczby punktów pomiarowych eksperymentu czynnego, co stanowi jedną z największych zalet proponowanego rozwiązania.

Słowa kluczowe: wtryskiwacz common rail, rozszerzenie procedur testowych, wzory Gaussa, dawkowanie paliwa

\section{INTRODUCTION}

Common rail fuel injectors are the most susceptible to damage elements of the fuel systems in modern compression-ignition engines [5]. For this reason, intensive research works on the development of various diagnostic methods have been carried out for several years. This applies to both non-invasive techniques, allowing to locate a malfunctioning fuel injector without the need to remove it from the engine, and invasive techniques, thanks to which it is possible to identify the causes of failure and eliminate them in tests on test benches. In the latter group of techniques, standard manufacturer's tests are usually used, which are commonly regarded as the most precise and reliable [7]. They are carried out in automatic cycles, and mainly concern the method of fuel delivery at several critical operating points [6]. However, there are problematic cases in which such measurements may turn out to be insufficient, because the fuel injector doses fuel incorrectly in other areas of the engine operation, despite the positive test result. As a result, the regeneration process requires extended diagnostics. It is particularly troublesome with the so-called injection characteristics, generated with the full spectrum of operating parameters, as the time consumption of the experimental phase increases several times [12]. In this respect, an interesting alternative are interpolation methods or methods based on linear regression, which effectively reduce the number of additional measurements $[3,17]$. However, they are less practical than the manufacturer's procedures, as they are performed with manual settings and, moreover, require some laboratory and workshop experience.

The above considerations justify the search for further solutions, which, based solely on the initial data, will enable the verification and assessment of a malfunctioning fuel injector. To achieve this goal, the analytical methodology based on Gaussian formulas was selected. It was assumed that the base points from the standard diagnostic test would be located and connected in a Cartesian coordinate 
system. In this way, the resultant fuel dosing areas of the tested fuel injector were calculated and compared with the reference fuel injector. The mathematical operations were carried out in the environment of Microsoft Excel spreadsheet, which enabled quick analysis of the experimental data. This approach was convenient from the practical point of view, as it allows taking into account the results from any test bench without having to interfere with its software.

\section{RESEARCH METODS}

The tests were carried out on the example of a Bosch CRI 2.1 fuel injector, which was removed from a 2.4 D5 compression-ignition engine of a Volvo C30 (533) vehicle with an operational mileage of $156,000 \mathrm{~km}$.

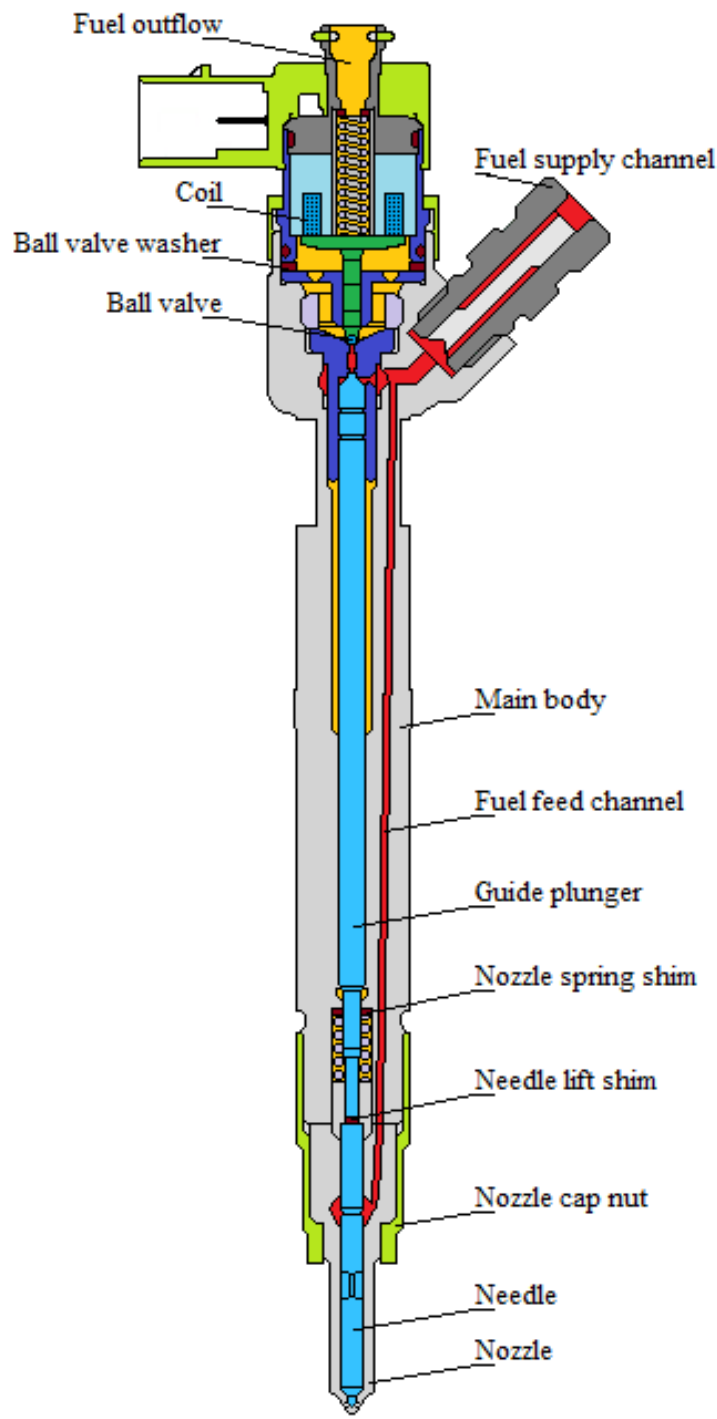

Fig. 1. Construction of the Bosch CRI 2.1 fuel injector

Electromagnetic fuel injectors of this type operate at maximum fuel delivery pressures of 160 MPa [8]. Their characteristic feature is the lack of a spring under the valve disc (Fig. 1). The simplified structure allows the regeneration to be carried out almost to the full extent. The manufacturer made available the diagnostic technology as well as a complete set of original spare parts [11].

\subsection{Test benches}

At individual stages of the research, the following measuring equipment and instrumentation were used, which included, among others:

- EPS 200 test bench (Fig. 2),

- the so-called Bosch 3-phase gear, e.g. CRR 120, CRR 220, CRR 320, CRR 420 (Fig. 3), LAB / SM135,

- SZM-168 laboratory microscope with a camera for digital image recording on a $\mathrm{PC}$,

- ultrasonic baths (Carbon Tech Ultrasonic Bath S15/C2, Elma Elmasonic S10H),

- presses, vices and fuel injector disassembly and assembly tool kits,

- tools and torque wrenches.

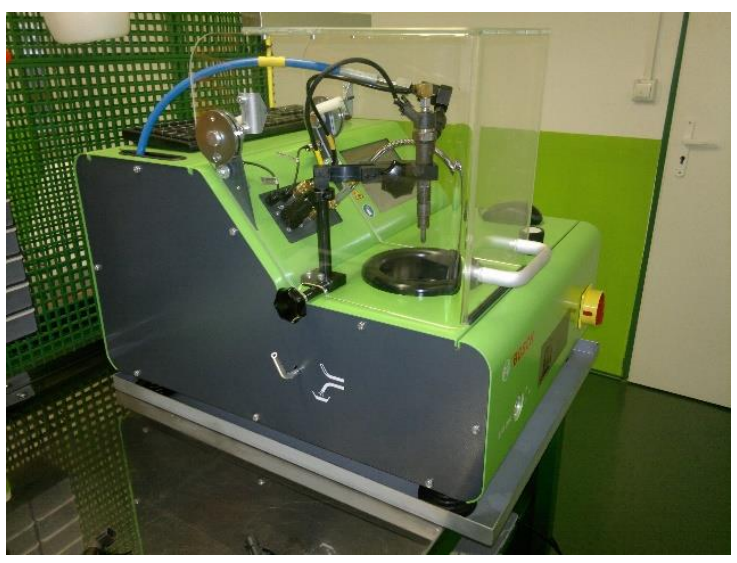

Fig. 2. Bosch EPS 200 test bench

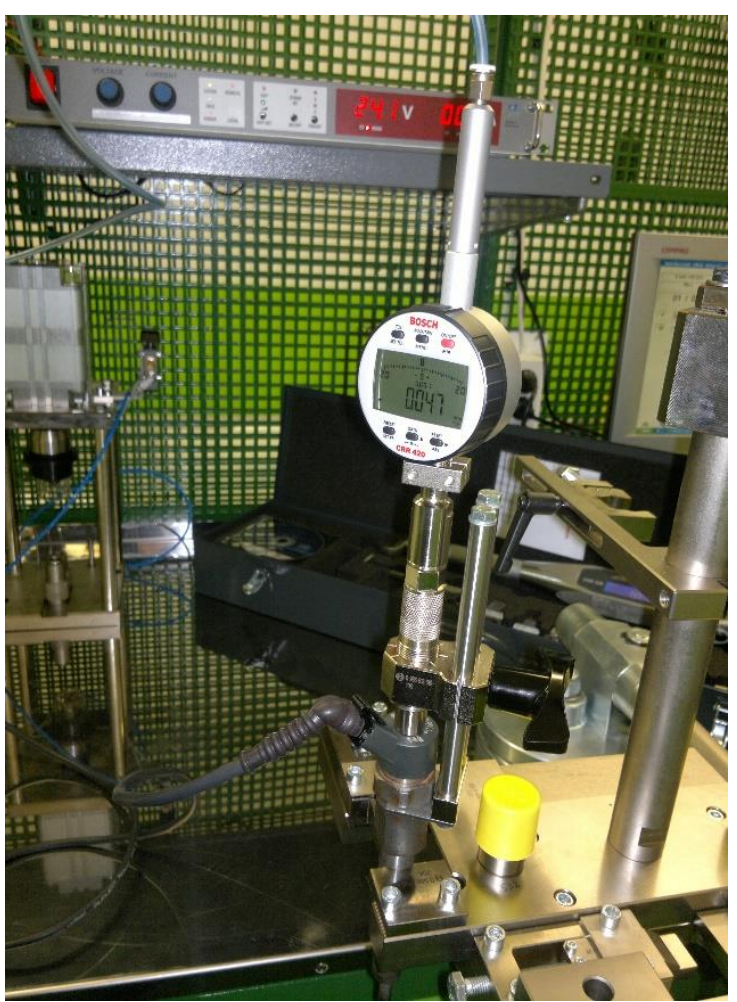

Fig. 3. CRR 420 digital dial gauge 
Before starting the tests, the fuel injector was mounted on a test bench and rinsed thermochemically. This decision was made in order to remove possible impurities and Internal Diesel Injector Deposits (IDIDs), the presence of which adversely affects the method of fuel delivery $[4,9$, $15]$.

The diagnostic process was carried out in accordance with the manufacturer's requirements. Therefore, the research included a dedicated Bosch 3-phase repair kit, which ensures the highest measurement accuracy and precision when correcting fuel dosage, being a standard equipment of the injection system regeneration laboratory.

\subsection{Gauss formulas}

In the proposed methodology, the area of the polygon, which is presented in the Cartesian coordinate system, is calculated on the basis of the coordinates of contour turn points [1]. Assuming that the vertices $\left.\mathrm{x}_{1}, \mathrm{y}_{1}\right),\left(\mathrm{x}_{2}, \mathrm{y}_{2}\right), \ldots,\left(\mathrm{x}_{\mathrm{n}}, \mathrm{y}_{\mathrm{n}}\right)$ are marked clockwise, the area of figure A can be determined using Gaussian formulas in the general form [10, 14]:

$$
A=\frac{1}{2}\left|\sum_{i=1}^{n} x_{i}\left(y_{i+1}-y_{i-1}\right)\right|
$$

and

$$
\boldsymbol{A}=\frac{1}{2}\left|\sum_{\mathrm{i}=1}^{\mathrm{n}} \mathrm{y}_{\mathrm{i}}\left(\mathrm{x}_{\mathrm{i}-1}-\mathrm{X}_{\mathrm{i}+1}\right)\right|
$$

where:

A - polygon surface area,

$\mathrm{n}$ - number of vertices,

$\mathrm{x}_{\mathrm{i}}, \mathrm{y}_{\mathrm{i}}$ - coordinated of the $\mathrm{i}$-th vertex.

Formulas (1) and (2) are also known as the socalled shoelace formulas because the vertex coordinates of the polygon are multiplied crosswise [2]. They should be used together in order to control the calculations made. On the other hand, it is most convenient to put the formulas created in the spreadsheet in the form of table 1 , which organises and simplifies the analytical process.

Table 1. Table for the calculation of surface areas

\begin{tabular}{|c|c|c|c|c|}
\hline $\begin{array}{c}\text { Point } \\
\text { number }\end{array}$ & $\mathrm{x}_{\mathrm{i}}$ & $\mathrm{y}_{\mathrm{i}}$ & $\mathrm{x}_{\mathrm{i}+1}-\mathrm{x}_{\mathrm{i}-1}$ & $\mathrm{y}_{\mathrm{i}+1-\mathrm{y}_{\mathrm{i}-1}}$ \\
\hline 1 & $\mathrm{x}_{1}$ & $\mathrm{y}_{1}$ & $\mathrm{x}_{2}-\mathrm{x}_{4}$ & $\mathrm{y}_{2}-\mathrm{y}_{4}$ \\
\hline 2 & $\mathrm{x}_{2}$ & $\mathrm{y}_{2}$ & $\mathrm{x}_{3}-\mathrm{x}_{1}$ & $\mathrm{y}_{3}-\mathrm{y}_{1}$ \\
\hline 3 & $\mathrm{x}_{3}$ & $\mathrm{y}_{3}$ & $\mathrm{x}_{4}-\mathrm{x}_{2}$ & $\mathrm{y}_{4}-\mathrm{y}_{2}$ \\
\hline 4 & $\mathrm{x}_{4}$ & $\mathrm{y}_{4}$ & $\mathrm{x}_{1}-\mathrm{x}_{3}$ & $\mathrm{y}_{1}-\mathrm{y}_{3}$ \\
\hline 1 & $\mathrm{x}_{1}$ & $\mathrm{y}_{1}$ & $\sum_{\mathrm{i}=1}^{\mathrm{n}}\left(\mathrm{x}_{\mathrm{i}+1}-\mathrm{x}_{\mathrm{i}-1}\right)$ & $\sum_{\mathrm{i}=1}^{\mathrm{n}}\left(\mathrm{y}_{\mathrm{i}+1}-\mathrm{y}_{\mathrm{i}-1}\right)$ \\
\hline
\end{tabular}

\section{RESULTS AND DISCUSSION}

\subsection{Preliminary tests}

Based on the data presented in Table 2, it can be concluded that the fuel injector passed the test procedure. The results obtained were within the limits specified by the manufacturer. However, after assembly, the engine was characterised by hard, uneven operation, particularly at idle and light loads.
For this reason, it was decided to implement the proposed methodology.

\begin{tabular}{|c|c|c|c|}
\hline \multirow{2}{*}{\multicolumn{2}{|c|}{$\begin{array}{l}\text { Leak Test, LKT }[\mathrm{MPa}] \\
170 \mathrm{MPa}(200 \mathrm{~s})\end{array}$}} & $\begin{array}{c}\text { Injection } \\
\text { dosage }\end{array}$ & $\begin{array}{l}\text { Return } \\
\text { dosage }\end{array}$ \\
\hline & & $\mathbf{0}$ & $\begin{array}{c}{[40.0 \pm 40.0]} \\
\mathbf{1 5 . 3 2}\end{array}$ \\
\hline \multicolumn{4}{|c|}{ Injector Volume Metering, IVM } \\
\hline $\begin{array}{c}\text { Dose } \\
\text { number }\end{array}$ & $\begin{array}{l}\text { Injection } \\
\text { pressure, } \\
\text { pinj }[\mathrm{MPa}]\end{array}$ & $\begin{array}{c}\text { Nozzle } \\
\text { opening } \\
\text { times, } \\
\mathrm{t}[\mu \mathrm{s}]\end{array}$ & $\begin{array}{c}\text { Injection } \\
\text { dosage, } \\
\mathrm{d}\left[\mathrm{mm}^{3} / \mathrm{H}\right]\end{array}$ \\
\hline 1 & 80 & 220 & $\begin{array}{c}{[1.4 \pm 1.1]} \\
\mathbf{1 . 2 3}\end{array}$ \\
\hline 2 & 160 & 1000 & $\begin{array}{c}{[43.6 \pm 6.0]} \\
\mathbf{3 9 . 9 1}\end{array}$ \\
\hline 3 & 80 & 600 & $\begin{array}{c}{[15.4 \pm 4.6]} \\
\mathbf{1 1 . 1 2}\end{array}$ \\
\hline 4 & 25 & 650 & $\begin{array}{c}{[3.2 \pm 3.0]} \\
\mathbf{0 . 2 2}\end{array}$ \\
\hline
\end{tabular}

Table 2. Results of the preliminary tests

The results of the volume measurements were located in the Cartesian coordinate system. The connection of the base points 1-2-3-4 made it possible to create an irregular quadrilateral whose surface area was estimated using the formulas (1) and (2). For this purpose, calculation formulas were entered into a Microsoft Excel spreadsheet. After substituting the numerical valuesconstituting the vertices of the analysed figure, the resultant fuel dosage area was obtained in the preliminary test $\mathrm{A}_{\mathrm{PT}}$ (Table 3).

Table 3. Calculation of the resultant metering field APT

\begin{tabular}{|c|c|c|c|c|}
\hline $\begin{array}{c}\text { Dose } \\
\text { number }\end{array}$ & $\mathrm{t}_{\mathrm{i}}$ & $\mathrm{d}_{\mathrm{i}}$ & $\mathrm{t}_{\mathrm{i}+1-\mathrm{t}_{\mathrm{i}-1}}$ & $\mathrm{~d}_{\mathrm{i}+1-\mathrm{d}_{\mathrm{i}-1}}$ \\
\hline 1 & 220 & 1.23 & 350 & 39.69 \\
\hline 2 & 1000 & 39.91 & 380 & 9.89 \\
\hline 3 & 600 & 11.12 & -350 & -39.69 \\
\hline 4 & 650 & 0.22 & -380 & -9.89 \\
\hline 1 & 220 & 1.23 & $\Sigma=0$ & $\Sigma=0$ \\
\hline \multicolumn{5}{|c|}{ APT } \\
\hline $\mathbf{1 1 6 2 0 . 7 0}=1 / 2 \mid(350 \cdot 1.23)+(380 \cdot 39.91)+(-350 \cdot 11.12)+$ \\
$+(-380 \cdot 0.22)$ \\
\hline \multicolumn{5}{|c|}{$+(-9.89 \cdot 650)$} \\
\hline
\end{tabular}

The calculations for the reference fuel injector were carried out in a similar way, using the data provided by the manufacturer (Table 4). In turn, Figure 4 shows a graphic interpretation of the results of the preliminary tests.

The disturbance of the fuel injection process causes a clear shift of the quadrilateral 1-2-3-4, and the position of individual vertices may indicate the cause of the malfunction. First of all, the very low idle dose value (point 4) is noteworthy. In such a situation, initial needle wear in the fuel injector atomiser often occurs, and thus problems with overcoming the nozzle spring tension after applying the lowest pressure on the test bench $\left(p_{i n j}=25 \mathrm{MPa}\right)$. It is worth emphasising that with the increase in this operating parameter, the symptoms almost 
completely disappeared. This is evidenced by the similar location of points 1-1, which correspond to the so-called pilot doses.

Table 4. Calculation of the resultant metering field AsI

\begin{tabular}{|c|c|c|c|c|}
\hline $\begin{array}{c}\text { Dose } \\
\text { number }\end{array}$ & $\mathrm{t}_{\mathrm{i}}$ & $\mathrm{d}_{\mathrm{i}}$ & $\mathrm{t}_{\mathrm{i}+1}-\mathrm{t}_{\mathrm{i}-1}$ & $\mathrm{~d}_{\mathrm{i}+1-\mathrm{d}_{\mathrm{i}-1}}$ \\
\hline $1^{`}$ & 220 & 1.40 & 350 & 40.40 \\
\hline 2 & 1000 & 43.60 & 380 & 14.00 \\
\hline 3 & 600 & 15.40 & -350 & -40.40 \\
\hline $4^{`}$ & 650 & 3.20 & -380 & -14.00 \\
\hline $1^{`}$ & 220 & 1.40 & $\Sigma=0$ & $\Sigma=0$ \\
\hline \multicolumn{5}{|c|}{$\mathrm{A}_{\mathrm{SI}}$} \\
\hline $\mathbf{1 0 4 5 2 . 0 0}=1 / 2 \mid(350 \cdot 1.40)+(380 \cdot 43.60)+(-350 \cdot 15.40)+$ \\
$+(-380 \cdot 3.20)$ \\
\hline $\mathbf{1 0 4 5 2 . 0 0}=1 / 2 \mid(40.40 \cdot 220)+(14.00 \cdot 1000)+(-40.40 \cdot 600)+$ \\
$+(-14.00 \cdot 650)$
\end{tabular}

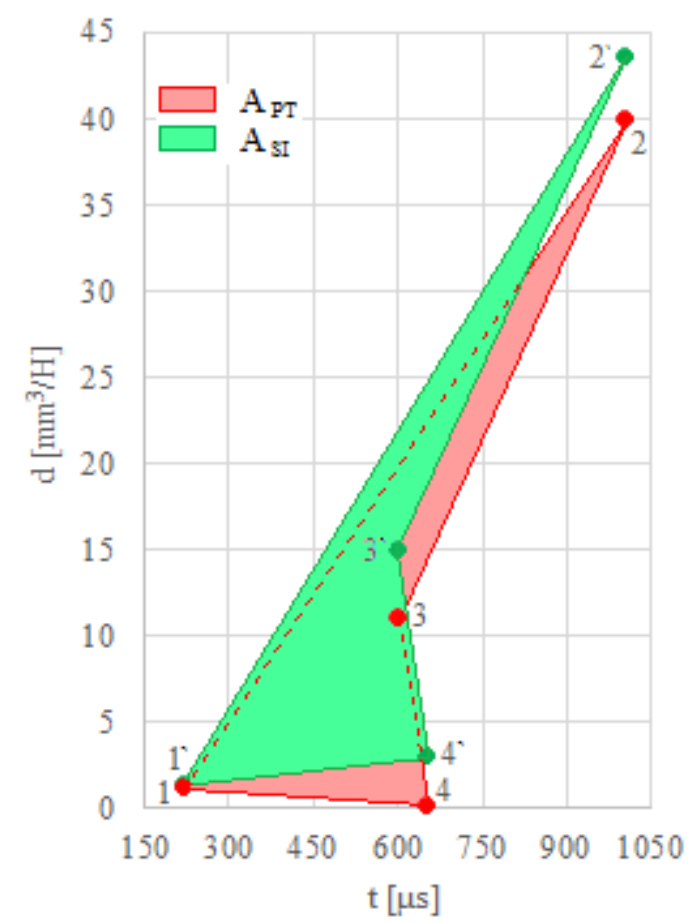

Fig. 4. Graphical interpretation of the preliminary test results

On the basis of the performed calculations, it was found that the difference between the resulting fuel delivery fields for the tested fuel injector APT and the reference fuel injector $\mathrm{A}_{\mathrm{SI}}$ was $10.06 \%$. Undoubtedly, this was due to the limited operating range of the control valve. At this stage of the research, however, it is not possible to clearly answer why the values of full load dose 2 and emission dose 3 were underestimated.

\subsection{Main tests}

In the first step, the valve ball travel $\mathrm{AH}$ (German: Ankerhub) was checked. The obtained result was $0.047 \mu \mathrm{m}$, which was within the limit set by the manufacturer (0.046-0.056 $\mu \mathrm{m}$ [13]). Therefore, there was no need to perform a setting correction that would require changing the thickness of the valve shim at the disc (Fig. 2).
Further basic tests were preceded by the disassembly of the fuel injector into its component parts, which were bathed in ultrasonic bathes. After drying them, microscopic examination was performed under high magnification. No damage was found to the valve assembly, as well as to plunger and barrel assembly, i.e. the needle with the atomiser (Figs. 5, 6 and 7).

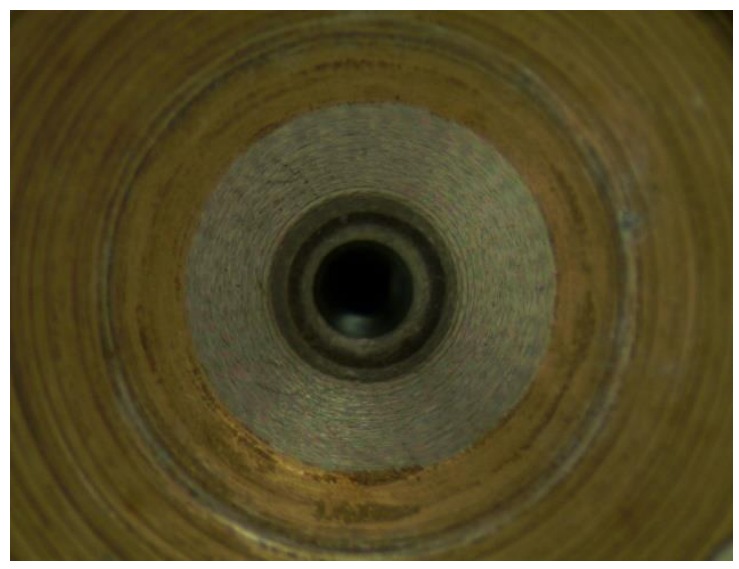

Fig. 5. View of the valve seat

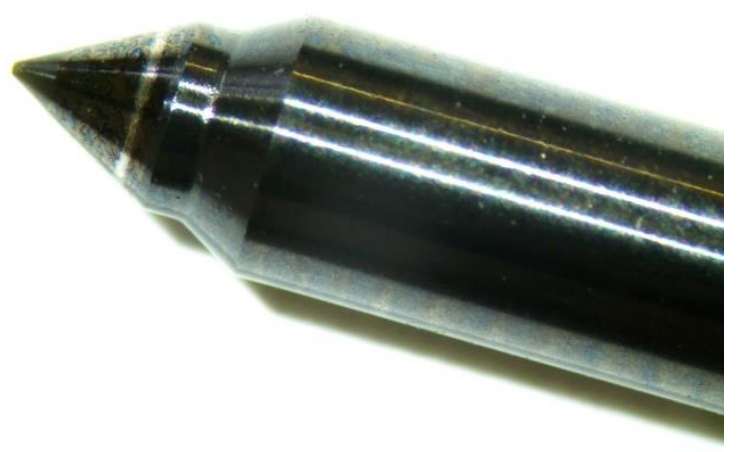

Fig. 6. Needle cone

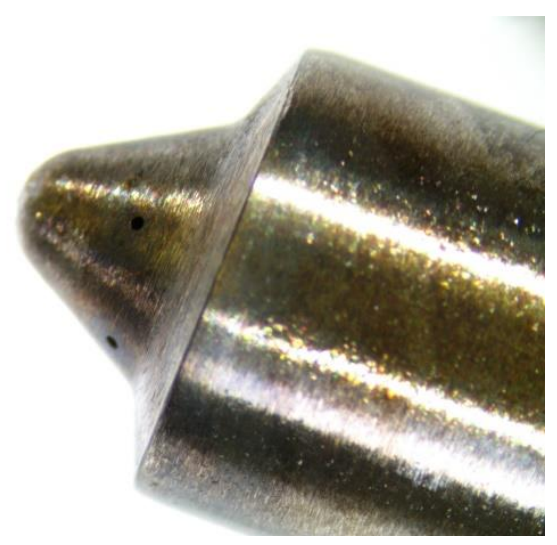

Fig. 7. Nozzle tip

Considering the low operational mileage of the engine, it was decided that no controls and actuators would be replaced with new ones. However, an adjustment was made, which consisted in increasing the idle doses and full load doses. For this purpose, the thickness of the needle washer was changed from 
$1.14 \mu \mathrm{m}$ to $1.10 \mu \mathrm{m}$, and then the nozzle spring disc were changed from $1.46 \mu \mathrm{m}$ to $1.26 \mu \mathrm{m}$.

Table 5. Results of the main tests

\begin{tabular}{|c|c|c|c|}
\hline \multirow{2}{*}{$\begin{array}{c}\text { Leak Test, LKT [MPa] } \\
170 \mathrm{MPa}(200 \mathrm{~s})\end{array}$} & $\begin{array}{c}\text { Injection } \\
\text { dosage }\end{array}$ & $\begin{array}{c}\text { Return } \\
\text { dosage }\end{array}$ \\
\cline { 2 - 4 } & $\mathbf{0}$ & $\begin{array}{c}{[40.0 \pm 40.0]} \\
\mathbf{9 . 3 2}\end{array}$ \\
\hline \multicolumn{4}{|c|}{ Injector Volume Metering, IVM } \\
\hline $\begin{array}{c}\text { Dose } \\
\text { number }\end{array}$ & $\begin{array}{c}\text { Injection } \\
\text { pressure, } \\
\text { pinj }[\mathrm{MPa}]\end{array}$ & $\begin{array}{c}\text { Nozzle } \\
\text { opening } \\
\text { times, } \\
\mathrm{t}[\mu \mathrm{s}]\end{array}$ & $\begin{array}{c}\text { Injection } \\
\text { dosage, } \\
\mathrm{d}\left[\mathrm{mm}^{3} / \mathrm{H}\right]\end{array}$ \\
\hline $1^{\prime \prime}$ & 80 & 220 & $\begin{array}{c}{[1.4 \pm 1.1]} \\
\mathbf{1 . 4 1}\end{array}$ \\
\hline $2^{\prime \prime}$ & 160 & 1000 & $\begin{array}{c}{[43.6 \pm 6.0]} \\
\mathbf{4 3 . 7 1}\end{array}$ \\
\hline $3 “$ & 80 & 600 & $\begin{array}{c}{[15.4 \pm 4.6]} \\
\mathbf{1 5 . 9 4}\end{array}$ \\
\hline $4^{\prime \prime}$ & 25 & 650 & $\begin{array}{c}{[3.2 \pm 3.0]} \\
\mathbf{2 . 4 5}\end{array}$ \\
\hline
\end{tabular}

Table 6. Calculation of the resultant metering field $\mathrm{A}_{\mathrm{MT}}$

\begin{tabular}{|c|c|c|c|c|}
\hline $\begin{array}{c}\text { Dose } \\
\text { number }\end{array}$ & $\mathrm{t}_{\mathrm{i}}$ & $\mathrm{d}_{\mathrm{i}}$ & $\mathrm{t}_{\mathrm{i}+1-\mathrm{t}_{\mathrm{i}-1}}$ & $\mathrm{~d}_{\mathrm{i}+1-\mathrm{d}_{\mathrm{i}-1}}$ \\
\hline $1^{\prime}$ & 220 & 1.41 & 350 & 41.26 \\
\hline $2^{\prime}$ & 1000 & 43.71 & 380 & 14.53 \\
\hline $3^{\prime \prime}$ & 600 & 15.94 & -350 & -41.26 \\
\hline $4^{\prime}$ & 650 & 2.45 & -380 & -14.53 \\
\hline $1^{\prime \prime}$ & 220 & 1.41 & $\Sigma=0$ & $\Sigma=0$ \\
\hline \multicolumn{5}{|c|}{$\mathrm{A}_{\mathrm{MT}}$} \\
\hline $\mathbf{1 0 5 9 3 . 3 0}=1 / 2 \mid(350 \cdot 1.41)+(380 \cdot 43.71)+(-350 \cdot 15.94)+$ \\
$+(-380 \cdot 2.45)$ \\
\hline $\mathbf{1 0 5 9 3 . 3 0}=1 / 2 \mid(41.26 \cdot 220)+(14.53 \cdot 1000)+(-41.26 \cdot 600)+$ \\
$+(-14.53 \cdot 650)$ \\
\hline
\end{tabular}

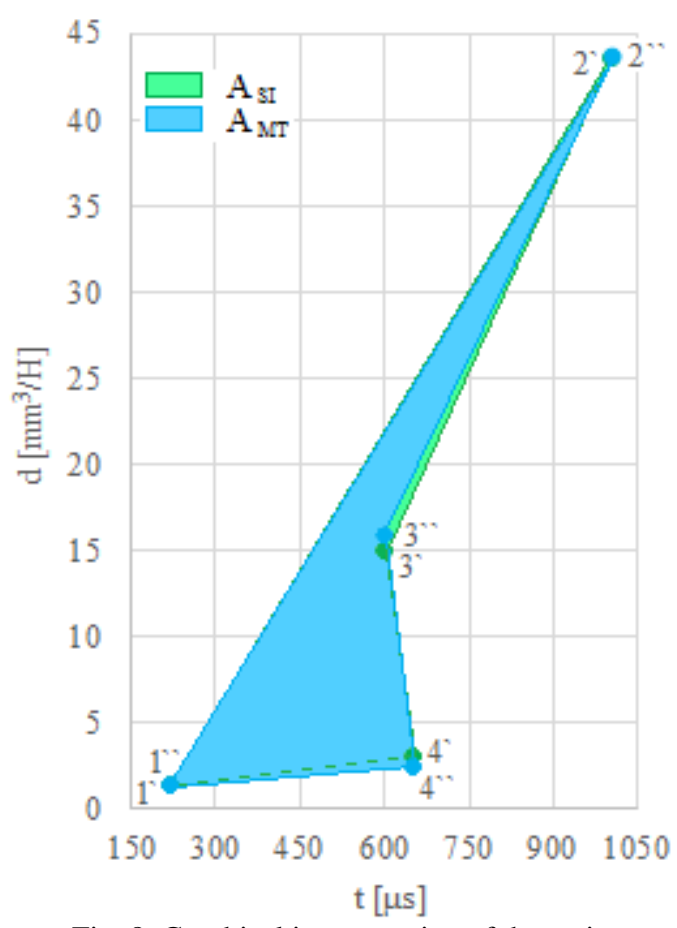

Fig. 8. Graphical interpretation of the main test results

The regeneration of the tested fuel injector should be assessed positively, as the factory settings have been restored (Tables 5 and 6). The resultant fuel dosage field $\mathrm{A}_{\mathrm{MT}}$ and the standard fuel dosage field $A_{S I}$ are comparable, as the difference between them was only $1.33 \%$. Therefore, the quadrilaterals $1 `-2 ` 3 `-4$ and 1 “'-2“-3“-4” practically overlap (Fig. 8). The vertices of the two figures have a very similar position on the graph, and the shifts so characteristic for the preliminary test are almost absent. The performed correction also had a positive effect on the pilot and emission doses (half load).

\section{CONCLUSION}

The proposed methodology of calculations makes it possible to consider specific cases of failure of common rail injectors that work incorrectly despite meeting the required manufacturer criteria. It is worth emphasising, however, that the resultant fuel dosage fields should be treated hypothetically (arbitrarily), as they do not reflect the actual fuel delivery method at intermediate points, i.e. beyond the vertices of the generated figures. Nevertheless, they can constitute a completely new diagnostic parameter, the analysis of which allows for the verification and assessment of the technical condition of the tested design, as shown in this particular example. Moreover, in the workshop and laboratory conditions, there is no need for a graphic interpretation of the obtained results, it is enough to compare them only, hence the drawings presented in the text are only illustrative. The added value is also that there is no need for additional measurements and calculations outside the test bench, without affecting its software in any way. For the above reasons, the presented solution meets the needs of the fuel injection system maintenance service market, which have been signalled in recent years. In addition, implementation in a digital environment allows the presented algorithms to be reused in research with a similar profile [16]. This approach is convenient from the practical point of view, because it enables a very quick analysis of experimental data that may come from diagnostic tests of fuel injectors of various types or generations.

In the analysed case, there were no malfunctions related to the wear of individual fuel injector component parts. The underestimated fuel dosage resulted from the presence of internal impurities, which were removed only when cleaning the disassembled elements in ultrasonic baths. On the other hand, the control and adjustment process made it possible to restore the original (factory) settings, as their values were comparable to the reference ones.

\section{REFERENCES}

1. Baldin N. Estimating the volume of a convex body. Snapshots of modern mathematics from Oberwolfach 2018; 15: 1-12.

https://doi.org/10.14760/SNAP-2018-015-EN 
2. Braden B. The Surveyor's Area Formula. The College Mathematics Journal 1986; 17(4): 326-337. https://doi.org/10.1080/07468342.1986.11972974

3. Busz W, Walaszczyk A. Optimize the testing process common rail fuel injectors. Combustion Engines 2015, 162(3): 978-981. Polish.

4. Hoffmann H, Feldhoff S, Koch W, Lucka K. Internal Diesel Injector Deposits: Investigations with the NonEngine Test "ENIAK". In: Tschöke H, Marohn R, eds. 10. Tagung Diesel und Benzindirekteinspritzung. Proceedings. Springer Vieweg, Wiesbaden; 2016. https://doi.org/10.1007/978-3-658-15327-4_13

5. Juściński S, Piekarski W, Chomik Z. Analysis of injection systems types used in agricultural machines. Agricultural Engineering 2017; 21(4): 37-46. https://doi.org/10.1515/agriceng-2017-0034

6. Karpiuk W, Bor W, Smolec, R. Possibilities of Analysis of Condition and Repair of Common-Rail System Injectors. Journal of KONES Powertrain and Transport 2018; 23(4): 209-216. https://doi.org/10.5604/12314005.1217208

7. Kluczyk M, Grządziela A. Vibration diagnostics of common rail injectors. Journal of Marine Engineering \& Technology 2017; 16(4): 177-184. https://doi.org/10.1080/20464177.2017.1387088

8. Landhäußer F, Sattmann H, Heinzmann R, Suseata ML, Rettich A, Brühmann W, Ortner K, Projahn U, Heinzelmann M, Wirth R, Schelhas P, Keller M, Soccol S, Strahberger H, Klam T, Holzer D, Koch A, Mattes P, Kügler T, Grosser M, Michalske A, Driedger G, Lehle W, Schauer W. High-pressure components of common-rail systems. In: Reif K, ed. Automotive Mechatronics. Automotive Networking, Driving Stability Systems, Electronics. Springer Fachmedien Wiesbaden; 2015.

https://doi.org/10.1007/978-3-658-03975-2

9. Makri K, Lockett RD, Jeshani M. Dynamics of PostInjection Fuel Flow in Mini-Sac Diesel Injectors Part 1: Admission of 1 External Gases and Implications for Deposit Formation. International Journal of Engine Research 2019: 1-47. https://doi.org/10.1177/1468087419895425

10. Ochilbek R., A new approach (extra vertex) and generalization of Shoelace Algorithm usage in convex polygon (Point-in-Polygon). 14th International Conference on Electronics Computer and Computation (ICECCO) 2018: 206-212. https://doi.org/10.1109/ICECCO.2018.8634725

11. Osipowicz T, Abramek KF. Diagnosing methods common rail fuel injectors. Combustion Engines 2017; 168(1): 56-61.

https://doi.org/10.19206/CE-2017-109

12. Osipowicz T, Kowalek S. Evaluation of modern diesel engine fuel injectors. TEKA. Commission of Motorization and Energetics in Agriculture 2014; 14(3): 83-88.

https://doi.org/10.1007/978-3-658-03975-2

13. Osipowicz T, Prajwowski K. Possibilities of research electromagnetic fuel injectors. Journal of KONES Powertrain and Transport 2017; 24(3): 167-176. https://doi.org/10.5604/01.3001.0010.2928

14. Pure R., Durrani S. Computing exact closed-form distance distributions in arbitrarily shaped polygons with arbitrary reference point. The Mathematica Journal 2015; 17: 1-27.

https://dx.doi.org/doi:10.3888/tmj.17-6

15. Stępień Z. A study of factors influencing the formation of harmful deposits in the diesel engine injectors.
Eksploatacja i Niezawodność - Maintenance and Reliability 2017; 19(3): 331-337.

http://dx.doi.org/10.17531/ein.2017.3.3

16. Stoeck T. Methodology of testing common rail fuel injectors witch the use of Gauss`s formulas. Combustion Engines. 2021; 184(1): 11-15. https://doi.org/10.19206/CE-133505

17. Stoeck, T. Simplification of the procedure for testing common rail fuel injectors. Combustion Engines 2020; 180(1): 52-56. https://doi.org/10.19206/CE-2020-109

Received 2021-01-11

Accepted 2021-04-21

Available online 2021-04-22

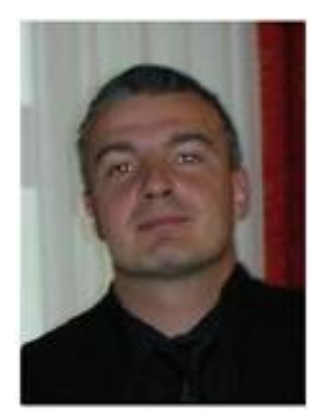

Tomasz STOECK, $\mathrm{PhD}$ graduated from the Faculty of Mechanical Engineering of the Szczecin University of Technology (currently ZUT in Szczecin). Since 2006, he has been a researcher and lecturer at the Department of Automotive Engineering. His interests are primarily related to the diagnosis and repair of diesel injection systems. 